\begin{tabular}{|cc|c|}
\hline ISSN (Online): 2367-6957 & ISSN (Print): 2367-6361 \\
Izvestiya Journal of Varna University of Economics 3 (2020) \\
J Z V E S T I Y A
\end{tabular}

\title{
THE MULTIANNUAL FINANCIAL FRAMEWORK OF THE EUROPEAN UNION AFTER 2020
}

\author{
Svetla BONEVA ${ }^{1}$, Filip PETKOV ${ }^{2}$
}

${ }^{1}$ Secretary General for Scientific Research Projects, University of National and World Economy,
Sofia, Bulgaria. Email: sboneva@unwe.bg
2 Department of International Economic Relations and Business, University of National and World
Economy, Sofia, Bulgaria. Email: f.petkov@unwe.bg

JEL: F15, F36

\begin{abstract}
The objective of the research is to summarise and analyse the proposal of the European commission concerning the Multiannual Financial Framework (MFF) of the European union (EU) for the period 2021-2027. The temporal scope of the research comprises the initial pre-covid ideas of the proposal that will be kept in the final post-covid version of the MFF which is currently under debate and is expected to be approved in the end of 2020. The research methods that have been used in the current research are: content analysis of European institutions' documents and of research papers analysing these documents; comparisons between different EU member states positions; and generalizations. As a result of the research the main conclusion is that the post-2020 MFF brings notable changes in structural terms. The most reformed category of expenditure is "Cohesion and Values" which combines several instruments from the MFF 2014-2020. Though there is no fundamental shift in the EU priorities, it can be argued that the cohesion policy and the common agricultural policy are seriously cut not only because of Brexit but also due to the redirection of budget resources to other priorities such as migration management, border control and security instruments.
\end{abstract}

Key words:

European union, Multiannual financial framework, European union budget.

(C) 2020 University of Economics - Varna

Citation: BONEVA, S., PETKOV, F. (2020). The Multiannual Financial Framework of the European Union after 2020. Izvestiya Journal of Varna University of Economics, 64 (3), p. 256 272. DOI: 10.36997/IJUEV2020.64.3.256 
S. Boneva, F. Petkov.

The Multiannual Financial Framework of the European Union after 2020

\section{Introduction}

The present discussion on the European union (EU) Multiannual financial framework (MFF) after 2020 is aligned with article 312 of Treaty on the Functioning of the European Union (TFEU) which defines a legal obligation for the Council to act unanimously after obtaining the consent of the European Parliament in order to adopt the new MFF (European union, 2016). The EU budget shall be compliant for each year of the MFF. The process of negotiations is based on a legal framework that includes not only the treaty cited above but also the adopted Interinstitutional Agreement between the European Parliament, the Council and the European commission as major stakeholders in the budgetary process and fiscal performance (European union, 2013).

The initial European commission proposal for a 2021-2027 MFF consists of 1 134583 million euro in commitments and 1104805 million euro in payments (2018 current prices). Those financial resources will be allocated into seven main thematic spending priorities: 1. Single Market, Innovation and Digital; 2. Cohesion and Values; 3. Natural Resources and Environment; 4. Migration and Border Management; 5. Security and Defence; 6. Neighbourhood and The World; 7. European Public Administration (European commission, 2018 a).

Notable increases in spending can be observed for Priority 1 - concerning innovation and digitalization, Priority 2 - focused on youth supporting initiatives (e.g. Erasmus + ), as well as for the migration and border policies. The MFF after 2020, still under negotiations, reflects the geopolitical agenda of EU and the Union ambition to be strategic and foremost innovator holding and developing advanced know-how and to protect its borders through the Integrated Border Management Fund.

The MAF is an important asset for furthering the European integration process. It has been introduced by article 269 of the Treaty establishing the European Community (article 269 of the Treaty establishing the European Community is the predecessor of articles 311-312 of the Treaty on the Functioning of the European Union which is currently in force for the EU) which stipulates that that the EU budget shall be solely financed from own resources. In the fundamental legislative act, the system of own resources is highlighted as an option providing the necessary means to implement the Union policies. Those own resources evolve till nowadays as supranational resources and their structure is currently under discussion for the period after 2020 when EU will consist of 27 member states again. Their structure will not only affect the amount of contributions to the budget but also sensitive and socially important sectors such as the common agriculture policy, the cohesion policy etc. The budget for the common agricultural policy 
will be cut by 5\% for the period 2021-2027 compared to the budget allocation for 2020 , according to an Impact Assessment, analysing the shrinking of the EU budget after the United ${ }^{\text {Kingdom }}$ withdrawal from the EU (European commission, 2018 b).

\section{Long-term multi annual financial planning in the European union: main implications}

Public budgets have one essential trait which is vital for the market and has socioeconomic implications - they determine what would be the course of action in the economic policy (expansion or restrictive policy) as well as what benefits or duties will be assigned to the business entities and citizens. Current political events always reflect budget negotiations' agendas, especially when it comes to budgets which carry supranational features in their nature - as it is the case of the MFF of the EU. The budgetary negotiation process is quite representative for the politics of a country (Wildavsky, 1992).

The above mentioned idea could be clearly tracked in the context of contemporary European affairs - EU institutions must produce a budget of high complexity considering national and regional specifics and expectations, protecting supranational strategic targets such as innovation, research, border integrity and market sustainability. This could be a point of intense political friction. "Spending priorities are discussed along national or party ideological lines, but the European council, the European commission, and the European parliament also have clear institutional interests', Becker, Bauer and de Feo affirm (2017).

Multi-annual financial planning was introduced originally in 1988 as a measure of the European Communities to tackle the crises of the late 1970s and 1980s. Open political confrontation between the Council and the Parliament had led to nonadoption of the annual budgets for 1980, 1985, 1986 and 1988.

The EU MFF stages of negotiations follow an inter-institutional path which begins with the European commission. The initial ideas lying in the basis of the MFF have been launched on May 2, 2018 when the Commission presented its' objectives and values in its' communication "A Modern Budget for a Union that Protects, Empowers and Defends - The Multiannual Financial Framework for 2021-2027" (European commission, 2018) which is the logical continuation of the "White Paper on the Future of Europe" (European commission, 2017 a). Once proposed, the European parliament shall review the proposal and declare its favourable position on it (especially concerning the Own resources decision) - after achieving a majority (article 312 of TFEU, 2016). Once approved, the Council of EU shall act anonymously in order to adopt the new MFF. In case anonymous outcome is 
S. Boneva, F. Petkov.

The Multiannual Financial Framework of the European Union after 2020

impossible and under special circumstances, the European council could be empowered to act by a qualified majority.

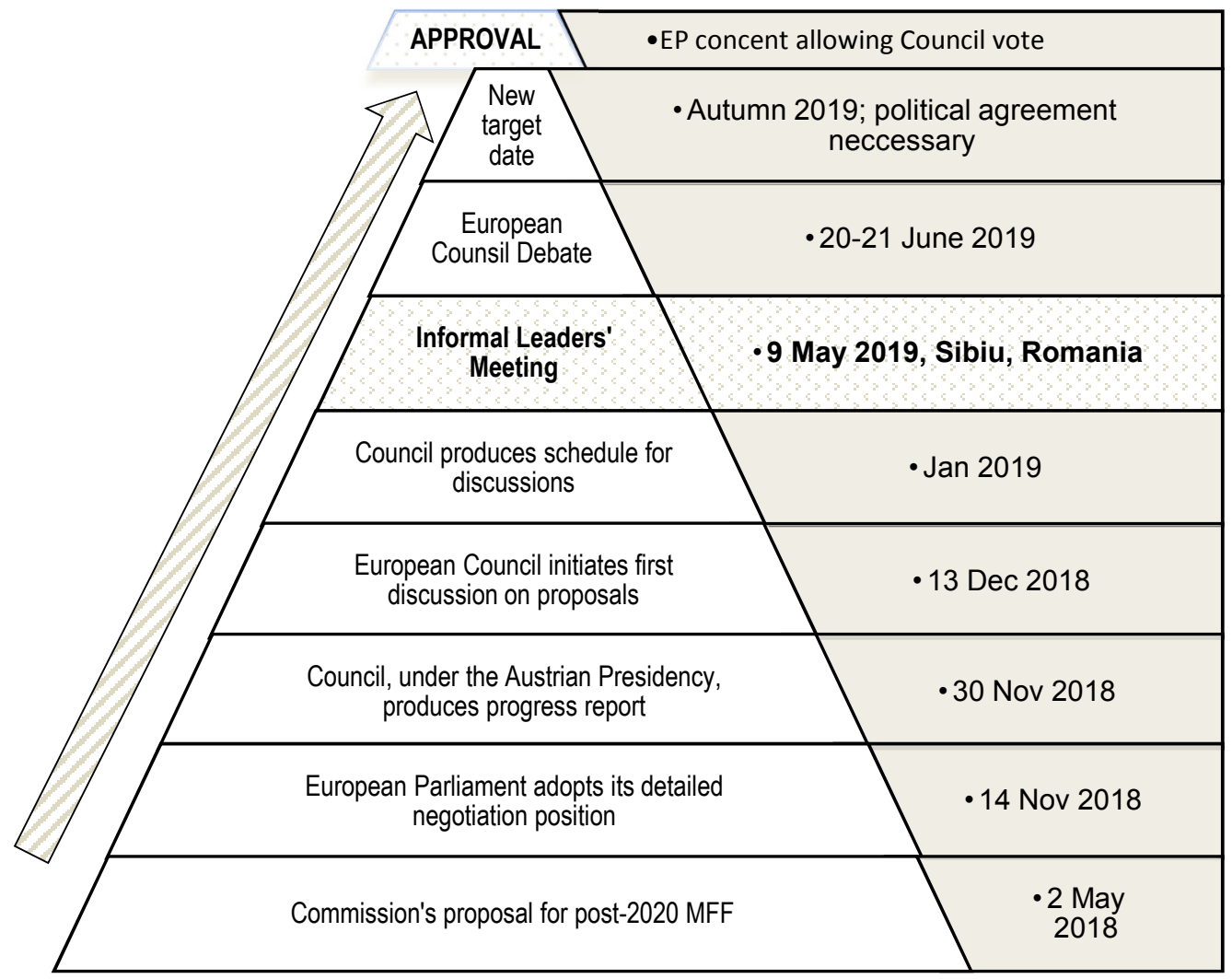

Fig. 1. Timeline of the MFF 2021-2027 negotiations

Source: the authors, based on information of the Interinstitutional Agreement of 2 December 2013 between the European Parliament, the Council and the Commission on budgetary discipline, on cooperation in budgetary matters and on sound financial management, OJ C 373, 20.12.2013, p. 1-11.

Negotiations stages are related to a great extend to the Council of the European Union and its presidency. The initial ambitious plan of the Commission to have the MFF approved before the elections for European Parliament that took place in May 2019 could not be achieved due to differentiations in the political views and priorities during the Council's presidencies. 
Several rotating presidencies have passed after the initial MFF proposal was made: the Bulgarian presidency (January-June 2018), the Austrian one (JulyDecember 2018), the presidency of Finland (July - December 2019), the Croatian presidency (January - June 2020), to give the lead to Germany (July-December 2020) which should adopt the final version of the long debated long-term Union financial plan. Looking back in time, we shall mention that the negotiations for the previous MFF (2014-2020) also lasted for more than 2 years.

The structural changes of the MFF are the main problematic area for several groups of countries in the present discussions on the post-2020 EU budget. A highlevel group study evaluated the potential elements of reforms, new resources and new expenditures of the budget as well as the link between the EU budget policy and the Eurozone (Ferrer J.N., Cacheux J.L., Benedetto G., Saunier, M., Candau F., Emonnot C., Lachet-Touya F., Mortensen J., Potteau A. and Taranic I., 2016). There are no radical reforms for the MFF for the period 2021-2027 when it comes to budget size or principle priorities, however, critical point of the negotiations proves to be the cohesion policy and the reshaped financing for this policy (Bulgarian Presidency of the Council of the European Union, 2018).

Reviewing the financial scale of the Commission's proposals, one could find a budget of 1,135 billion euro in commitments (2018 prices) for the period 2021-2027, equivalent to $1.11 \%$ of EU-27 GNI. This amount includes the "European Development Fund" (EDF), which was off-budget during the 2014-2020 programming period. Only the "African Peace Facility" (part of the "European Development Fund" so far) will be absorbed into the new "European Peace Facility" and remain outside the EU budget for the period 2021-2027. The budgeting of the "European Development Fund" through the MFF would increase its efficiency and effectiveness through enhanced visibility of the spending (D' Alfonso, 2014).

Apart from the cohesion policy, there is a decreased financing in the common agricultural policy. This led to joint memorandum between Ministers of agriculture from Finland, France, Greece, Ireland, Portugal and Spain highly regretting the proposed cuts and expressing concerns about the viability of European farms (National Rural network, 2018).

Another question of European budgeting and fiscal discipline incorporates the traditional political cultures of the member states (Brunnermeier, James and Landau, 2018). Germany raises concerns on the fairness of the burden-sharing mechanisms and the no-bail out clause which will serve as a reason for certain national economies to perform well and imply strict fiscal discipline. On 19th June 2018, the French and German leaders announced their joint support for a euro area budget, an idea that has 
been periodically launched for discussions but has never been implemented so far (Mahreen, 2018). Regarding the spending part of the budget, it is worth mentioning the observation of White and Wildavsky (1989) on the budget deficits in the USA during the 80 's. The researchers claim that budget deficiencies are products of different value systems. They presume that moderate deficit is tolerable as we should not lose the focus on other questions.

The cohesion policy and the common agricultural policy are not the only areas where differentiations are observed. The increased size of the national instalments into the income part of the future EU budget will count for $1.3 \%$ of member states' GNI - a fact that raises concerns in the Dutch, Swedish, Austrian and Danish governments.

Romania supports $1 \%$ contribution of GNI but does not reject opportunities for increase of this percentage in the course of negotiations on the MFF. The government, however, express concerns over the changes in the cohesion policy and highlights the necessity for basic infrastructure in all sectors (Romanian preliminary position, 2017).

Greece supports the current size of the budget and the new priorities as well as the introduction of a Common consolidated corporate tax (CCCT) and a tax on the global digital companies which Greece finds will be beneficial to the system of the own resources.

The political decision to proceed with Brexit has important consequences for the post-2020 MFF: the percentage of contributions based on GNI increases and there will be cuts in the cohesion policy funding $(-10 \%)$ and the common agricultural policy budget (-15\%), both socially viable policies of EU. Slovenia, Croatia, Portugal, Lithuania, Latvia, Czech Republic, Romania, Italy and Spain are among the countries benefitting and logically oppose cuts in the cohesion policy. Altogether, the tree funds that form up the cohesion policy (the European Regional Development Fund, the Cohesion Fund and the European Social Fund) are to be affected differently (European Court of Auditors, 2018):

- the European Regional Development Fund is to increase by $2 \%$, in line with the evolution of the whole heading;

- for the Cohesion Fund will be reduced by 45\% (according the European commission proposal);

- the allocations to the European Social Fund will be reduced by $7 \%$.

The debate on the cohesion policy reform is not new to the European budgeting process and the EU agenda. It has been renewed back in 2015-16 when stakeholders were reviewing ex-post data from 2007-2013 period. The cohesion policy at that time has been divided into 14 packages. The macroeconomic modelling showed that 
cohesion and rural development spendings in the EU-12 led to a GDP increase by 4\% in 2015 above what it otherwise would have been (Applica and Ismeri Europa, 2016).

Another group of reforms that rise concerns are related to migration, asylum, border security and promoting stability in European union's neighbourhood. Some of the measures in the financial framework proposed were proclaimed by the Bratislava declaration (September 2016) and the Rome declaration (March 2017) of the heads of the EU-27 member states. Netherlands, Sweden, Austria, Denmark and Finland are in favour of allocating more financial resources for migrant policies, innovation and climate. Portugal and Greece are as well supportive towards better migration management but not via old traditional instruments. Germany approves higher expenditure on migration, climate change, security and defence (Die Bundesregierung, 2018).

A proposal on engaging the "rule of law" as a criterion for member states which are net beneficiaries of EU funding sparked an intense political debate among the leaders of certain countries (Hungary and Poland) and the European commission (European Commission, $2018 \mathrm{c}$ ).

The main issues concerning the cohesion policy and the common agricultural policy were not resolved during the Bulgarian presidency of the Council of the EU which supported the Commission's proposal for structural changes of the MFF and cohesion policy reforms, and have been forwarded to the Austrian presidency. Thus, the structure of the MFF proposal was kept the same. The issue remained pending in the Romanian's presidency agenda and was not solved in May 2018 at the EU summit in Sibiu (Romania). It is of a high importance to continue the constructive negotiations on the MFF. This increases the hopes for significant outcome during the EU leaders' meeting scheduled for the autumn of 2020 in Germany (during the German presidency of the Council of the EU).

Brexit is another hot issue of discussion for policy makers and economists who try to measure the impact of the United Kingdom's departure from the EU. We should not deny the importance of this political event which is a step back after years of dedicated efforts for European integration by number of British cabinets and politicians. The United Kingdom was one of the countries benefiting most from the cohesion policy revised financial envelope for 2017 after Greece, Spain and Italy. Serious impact after the United Kingdom's departure would be imposed on Germany which might have to increase its GNI based contributions with $9 \%$ followed by France with 7\% (Nunez-Ferrer and Rinaldi, 2016).

There is also a positive effect stemming from the United Kingdom's withdrawal from European Union. Enderlein (2016) suggests that such an event could lead to 
detailed review of Europe's budgetary framework, developing a stronger system of own resources and better distribution of power between the European commission and the EU member states.

While it can be assumed that the EU will adapt to the missing contributions from the United Kingdom through structural changes of the MFF and revision of the spending per policy areas, the UK might face quite serious trade pressure with immediate effect. Consumers might experience tariffs increases of $30-40 \%$ on cheese and wine which UK imports from EU-based producers (Van Berkum, Jongeneel, Vrolijk, Van Leeuwen, and Jager, 2016). The same research finds out that import tariffs could reach the interval between $70-90 \%$ for certain meat products. The expected budget receivables will go into the United Kingdom national budget, while their reciprocal taxes and tariffs levied by the EU Generalised customs tariff on the imports coming from the United Kingdom will contribute to the EU budget income part.

According to other group of authors, there will be a 94 billion euro Brexitrelated gap in the EU budget for 2021-27 if the United Kingdom no longer contributes (Darvas and Wolff, 2018). To tackle the situation before increasing the MFF in absolute terms, restructuring and shifting spending between categories could be an option to explore (Busch and Matthes, 2018). Strong remarks that the newly proposed MFF is rather reactionary than future-oriented (Van Deuverden, 2018) bring concerns on the increased funding for new instruments (or instruments outside the budget) on the account of decrease in old policies. Measures supporting the euro shall also be applied by the member states. Van Deuverden (2018) concludes also that there should be some place for financial leeway in order to reach a consensus on the post-2020 issues.

\section{Structure of the Multiannual financial framework}

\section{for the period 2021-2027}

The European Commission has proposed a new Multiannual Financial Framework for the period 2021-2027 fit for 27 member states. It has been revised regarding the United Kingdom departure from the EU and suggests also changes in the revenue side of the balance sheet which reflect the contemporary economic realities and opportunities.

The initial MFF post-2020 proposal is totalling 1134583 million euro in commitments and 1104805 million euro in payments (2018 prices). Comparisons of the proposed MFF with the current one as well as with previous budgets should be done with caution as the structure of the programs/instruments has changed over time. 
However, we can easily compare the share of GNI that each country contributes to the EU budget. According the proposal (European commission, 2018), countries must deliver $1.11 \%$ of their GNI to compile the EU-27 post-2020 MFF own resources system. This is a slight increase compared to the MFF 2014-2020 with 28 member states where this percentage has been $1.03 \%$ of GNI.

Haas, Rubio and Schneemelcher (2018) come to the conclusion that the proposal is larger in nominal and real terms than the previous MFF, but smaller in terms of the EU-27 GNI, after the United Kingdom's withdrawal. The consequences of this will inevitably cause changes among the EU priorities and programs such as the cohesion policy.

The proposed budget structure consists of seven thematic spending priorities that form policy clusters:

I. Single Market, Innovation and Digital:

1) Research \& Innovation;

2) European Strategic Investments;

3) Single Market;

4) Space.

II. Cohesion and Values:

1) Regional Development \& Cohesion;

2) Economic \& Monetary Union;

3) Investing in People, Social Cohesion \& Values.

III. Natural Resources and Environment:
1) Agriculture \& Maritime Policy;
2) Environment \& Climate Action.

IV. Migration and Border Management:
1) Migration;
2) Border management.

V. Security and Defence:
1) Security;
2) Defence;
3) Crisis response.

VI. Neighbourhood and the world:

1) External Action (excluding the European Peace Facility which remains out of MFF);

2) Pre-accession assistance.

VII. European Public Administration. 
S. Boneva, F. Petkov.

The Multiannual Financial Framework of the European Union after 2020

The following financial instruments remain outside of the post-2020 budget framework (Table 1):

- Emergency Aid Reserve;

- EU Solidarity Fund;

- European Globalisation Adjustment Fund;

- Flexibility Instrument;

- European Investment Stabilisation Function;

- European Peace Facility.

Table 1

\section{EU programmes outside of the scope of the Multiannual financial framework for the period 2021-2027}

\begin{tabular}{|l|l|}
\hline \multicolumn{1}{|c|}{ Programme } & \multicolumn{1}{c|}{ Function } \\
\hline $\begin{array}{l}\text { Emergency Aid Reserve } \\
(€ 280 \text { million / year })^{*}\end{array}$ & $\begin{array}{l}\text { Humanitarian operations and specific aid-requirements for } \\
\text { non-EU countries (unforeseen situations) }\end{array}$ \\
\hline $\begin{array}{l}\text { EU Solidarity Fund } \\
(€ 500 \text { million / year)* }\end{array}$ & $\begin{array}{l}\text { Emergency financial aid allocated after major disaster } \\
\text { occurred on the territory of member states or prospective } \\
\text { candidate countries }\end{array}$ \\
\hline $\begin{array}{l}\text { European Globalisation } \\
\text { Adjustment Fund } \\
(\leq € 150 \text { million / year })^{*}\end{array}$ & $\begin{array}{l}\text { Reintegration of workforce back into the labour market in case } \\
\text { of disruptions / displacement in the global trade patterns }\end{array}$ \\
\hline $\begin{array}{l}\text { Flexibility Instrument } \\
(\leq € 471 \text { million / year)* }\end{array}$ & $\begin{array}{l}\text { Serves as a financial buffer assisting in covering clearly } \\
\text { identified expenses which could not be covered by one or } \\
\text { more budget headings without exceeding their expenditure } \\
\text { ceilings on annual basis }\end{array}$ \\
\hline $\begin{array}{l}\text { European Investment } \\
\text { Stabilisation Function } \\
(€ 600 \text { million / year)** }\end{array}$ & $\begin{array}{l}\text { Provides assistance to absorb asymmetric shocks and spill- } \\
\text { overs between the member states; Non-euro area member } \\
\text { states may voluntarily participate }\end{array}$ \\
\hline $\begin{array}{l}\text { European Peace Facility } \\
(€ 10.5 \text { million / year) }\end{array}$ & $\begin{array}{l}\text { Off-budgetary instrument to support the military operations } \\
\text { under the Common Security and Defence Policy as well as to } \\
\text { prevent conflicts and instability in third countries }\end{array}$ \\
\hline
\end{tabular}

* - Calculations in 2011 prices by the European Commission

** - Calculations in 2018 prices by the European Commission

Source: European commission. (2018 a). A Modern Budget for a Union that Protects, Empowers and Defends - The Multiannual Financial Framework for 2021-2027, Communication from The Commission, COM (2018)321 final, Brussels, 2.5.2018.

While composing the MAF proposal, the European Commission has been led by new challenges evolving in the socioeconomic reality as well as the European added 
value principle meaning that pooling financial resources on EU level and allocating them into supra-national strategies would deliver better results to the EU strategic objectives than if this was done by single governments at national level.

That is why the first spending priority ("Single Market, Innovation and Digital") is related to delivering efficient single market, supporting the innovation efforts and digitalizing the economy. The new research programme "Horizon Europe" will be the basic instrument to perform research activities and support innovation initiatives by government and non-government entities in strive to keep the EU as a world leading technology developer. The proposed European Innovation Council will be the administrative solution for regulating and coordinating the research and development activities which are essential for meeting the goals of the EU after 2020. The "InvestEU" facility will support the private investment while the "Connecting Europe Facility" will continue the development of cross-border infrastructure which is needed for expanding the business relations across Europe. Digitalization is also highlighted as one of the foremost action fields. An example with the 50-years Customs Union will be appropriate to demonstrate the necessity of digitalizing the governing processes. Practises of tax avoidance and tax fraud could be retrenched through better traceability and information exchange.

The second heading "Cohesion and Values" has been affected by several structural changes. As previously discussed, the Cohesion policy triggers the political discussions which impede the consensus on the MFF by the most affected member states. The purpose of the cohesion policy will remain to be tackling the disparities in the EU regions. The political priorities agreed in Bratislava and Rome will also be delivered through sustainable cohesion in the European commission's view. The European Semester is considered important to review the country specific recommendations and to utilize the necessary tools from the existing programs in order to overcome the problematic areas.

Several instruments have been proposed to stabilize the Euro-area and to be incorporated in the post-2020 MFF (European Commission, 2017 b). They are important to complete the Roadmap for completing the Europe's Economic and Monetary Union (European Commission, 2017 c). The budgetary instruments that directly or indirectly support the Economic and Monetary Union are briefly summarized on Figure 2. 
S. Boneva, F. Petkov.

The Multiannual Financial Framework of the European Union after 2020

European Monetary Fund (or

European Stability Mechanism)

European Investment Bank

EU Structural and Investment Funds

Reform Support Programme

InvestEU

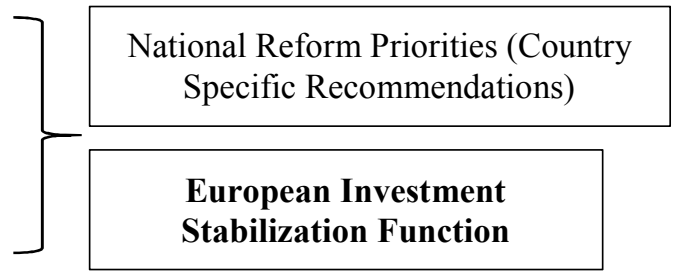

\section{Fig. 2. The Multiannual financial framework 2021-2027 instruments in support of the EU Economic and Monetary Union}

Source: the authors, based on the European Commission's proposal "New budgetary instruments for a stable Euro area within the Union framework", COM (2017) 822 final and on the European Commission's proposal "Further steps towards completing Europe's Economic and monetary union: a roadmap”, COM (2017) 821 final.

Social cohesion is another aspect where the Commission sees possible area for improvement. Thus, an increase can be observed in the "Erasmus + " programme which reaches a budget of 30 billion euro.

The heading "Natural Resources and Environment" reveals changes in the common agricultural policy funding. The European commission intends to keep the instruments of direct payments to farmers ( 286.2 billion euro have been allocated for this) and the rural development programs (EUR 78.8 billion euro) however the funding for them will be decreased in comparison to the previous MFF.

The complex system of rebates will be gradually dissolved in the forthcoming years. An emphasis is made on the United Nations' Sustainable Development Goals the common agricultural policy will spend $25 \%$ of its budget for climate actions and eco-innovations (Gallucci, Dimitrova and Marinov, 2019).

There is a strong focus on the migration and border management in the post2020 multiannual framework. The political will to effectively guard the EU borders and respond to the incoming migration flows will absorb 33 billion euro via heading IV "Migration and Border Management" compared to only 12.4 billion euro for similar activities for the period 2014-2020.

Increased spending in thematic priority V "Security and Defence" is in line with the overall efforts to manage the external threats and to improve the defence capabilities of the member states. The proposed "Internal Security Fund" will facilitate an efficient internal network to respond jointly to common threats as well as cybersecurity dangers. In addition to that the European Union Agency for Law Enforcement Cooperation (Europol) will be further enforced. 
Bulgaria, Slovakia and Lithuania would benefit from the increased spending in this financial envelope as funds will be allocated to them for safe decommissioning of nuclear energy power plants. The European Defence Union has been a desired path for certain countries (France) as opposed to others (Talaga, 2017). In February 2018 the Commission once again emphasised the necessity to develop the European Defence Union through additional financial support: for 2017 - 2019 the European Defence Union budget has been increased to 90 million euro aimed at defence research and innovation (European commission, $2018 \mathrm{~d}$ ). The same idea is reconfirmed in the post2020 MFF through the European Defence Fund which shall foster competitiveness in the defence and security fields. The Civil Protection Mechanism ("rescEU") receives 2.5 times higher budget compared to the MFF for the period 2014-2020.

1.8 times more resources (in comparison to the previous MFF) are allocated for the "Internal Security Fund" while probably the most sensitive issue is the 22 times increase in the funding for the "Defence fund" which will receive 24323 million euro (2018 prices). For comparison, the "Security and Citizenship" goal of the MFF for the period 2014-2020 equals to 18003 million euro (2018 prices).

Significant changes have been proposed in heading VI "Neighbourhood and the World". Striving to achieve efficiency and better interlinks between different instruments, the European commission proposes external action towards the EU neighbourhood and third countries to be transformed into three pillars: "Neighbourhood, Development and International Cooperation Instrument"; "Humanitarian Aid Instrument" and "Instrument of Pre-accession assistance" (European Commission, 2018 e). The incorporation in this heading of the European Development Fund (EDF) which provides assistance to the African, Caribbean and Pacific countries will ease the administrative burden and increase the transparency and flexibility. The debates here are provoked by the fact that the inclusion of the European Development Fund in this heading will increase the contributions of the member states in terms of the own resources ceilings.

Heading VI has a budget of 108292 million euro (2018 prices) most of which will be spent on the "Neighbourhood, Development and International Cooperation Instrument" (over 79 million euro, 2018 prices). The structure of this heading is an example of the European commission's new approach to restructure the MFF through inclusion of the EU foreign financial aid into it (the EDF is included within the budgetary ceiling). The "European Peace Facility" remains extra-budgetary and it will complement the Common Security and Defence Policy.

The "European Public Administration" (heading VII) has 75602 million euro budget allocated for supporting the administrative structures, the pensions paid by the 
EU and the European Schools. The agreement for reducing the staff in the EU institutions by $5 \%$ (signed back in 2013) has achieved its targets according to the European commission. Notwithstanding there is a slight increase in this spending priority - it comprises $6.7 \%$ of the post-2020 MFF while it is $6.2 \%$ of the pre-20202 MFF of the European union. Additionally the redistribution of certain functions as a result of Brexit will affect to some extent the European administration.

\section{Conclusion}

The negotiations for the MFF 2021-2027 will pave the way for the European Union in a landmark period. Through the new multiannual framework the EU will declare its strategic position as global centre for innovation, sustainable economy and growth. Brexit has brought changes in the structure of MFF. Along with the budgetary gap of 12-14 billion euro, there is however a positive effect stemming from Brexit - the European commission initiated modernization of the budgetary structure and gradual removal of the rebate payment schemes - considered obsolete and ineffective.

Changes in the MFF structure review the financial ceilings for certain headings and programs. The debate is predominantly related to the cohesion policy and the common agricultural policy which decrease their ceilings. Significant financial resources relocated to new priority areas as a result of recent events - and increase in the funding for priority areas such as single market, innovation, security, defence, migration and border management can be observed.

\section{References}

1. Applica and Ismeri Europa. (2016). Ex post evaluation of Cohesion Policy programmes 2007-2013, focusing on the European Regional Development Fund (ERDF) and the Cohesion Fund (CF), WP1: Synthesis report, Luxembourg: Publications Office of the European Union, Available at: https://op.europa.eu/en/ publication-detail/-/publication/e9182ca7-7a40-11e6-b076-01 aa75ed71a1[Accessed 30.01.2020].

2. Bachtler J., Mendez C. and Wishlade F. (2016). Evolution or revolution? Exploring New Ideas for Cohesion Policy. 2020+, EoRPA Paper 16/4, European Policies Research Centre, University of Strathclyde, Glasgow.

3. Becker, S., Bauer, M. and de Feo, A. (2017). The New Politics of the European Union Budget: Background, Key Findings, and Outlook, pp.15-32, DOI: 10.5771/9783845278032-15. 
4. Brunnermeier M., James H. and Landau J.-P. (2018). The Euro and the Battle of Ideas, Princeton University Press.

5. Bulgarian Presidency of the Council of the European Union. (2018). High Level Conference Dedicated to EU Cohesion Policy: post-2020 Perspectives for Convergence and Sustainable Regions, Background paper, Sofia, 8th June 2018.

6. Busch, B. and Matthes, J. (2018). On the future of the European Union: Normative derivation and restructuring potential in the new Multiannual Financial Framework (No. 10/2018). IW Policy Paper, No. 10/2018, Institut der deutschen Wirtschaft (IW), Köln, Germany.

7. D'Alfonso A. (2014). European Development Fund. Joint development cooperation and the EU budget: out or in?, EPRS, European Parliament, November 2014.

8. Darvas, Z. and Wolff, G. B. (2018). Rethinking the European Union's postBrexit budget priorities. Bruegel Policy Brief, Issue 1, March 2018.

9. Die Bundesregierung. (2018). The Federal Government's positions on the EU Multiannual Financial Framework (MFF) post-2020, 25 January 2018, Available at: https://www.bundesregierung.de/resource/blob/998352/600324/7243e962ceb4c4af22f bc26889c53839/2018-02-22-mehrjaehriger-eu-finanzrahmen-endata.pdf?download=1 [Accessed 30.01.2020].

10. Enderlein, H. (2016). What should happen? What is likely to happen? Notes on Brexit. Policy Paper, Jacques Delors Institute-Berlin, 30 June.

11. European commission. (2017 a). White Paper on the Future of Europe, European Commission COM (2017) 2025, 1 March 2017, Brussels.

12. European Commission. (2017 b). Proposal "New budgetary instruments for a stable Euro area within the Union framework', COM (2017 c) 822 final.

13. European Commission. (2017). Proposal "Further steps towards completing Europe's Economic and monetary union: a roadmap", COM (2017) 821 final.

14. European commission. (2018 a). A Modern Budget for a Union that Protects, Empowers and Defends - The Multiannual Financial Framework for 20212027, Communication from The Commission, COM (2018)321 final, Brussels, 2.5.2018.

15. European commission. (2018 b). Commission Staff Working Paper - Impact assessment, SWD (2018) 301 final, Brussels, 1.6.2018.

16. European Commission. (2018 c). Proposal for a Regulation of the European Parliament and of the Council on the protection of the Union's budget in case of generalised deficiencies as regards the rule of law in the Member States, COM/2018/324 final - 2018/0136 (COD) 
17. European commission. (2018 d). "\#EUDefence: Towards a European Defence Union - Towards a More United, Stronger and More Democratic Union", February 2018, Available at: https://ec.europa.eu/commission/sites/betapolitical/files/towards-a-european-defence-union_en.pdf [Accessed 30.01.2020].

18. European Commission. (2018 e). Proposal for a Regulation of the European parliament and of the Council establishing the Neighbourhood, Development and International Cooperation Instrument, COM(2018) 460 final 2018/0243 (COD) Brussels, 14.6.2018

19. European Court of Auditors. (2018). Briefing paper "The Commission's proposal for the 2021-2027 Multiannual Financial Framework”, Review No 06/2018, July 2018, Luxembourg, Available at: https:/www.eca.europa.eu/en/ Pages/DocItem.aspx?did=46593 [Accessed 30.01.2020].

20. European union. (2013). Interinstitutional Agreement of 2 December 2013 between the European Parliament, the Council and the Commission on budgetary discipline, on cooperation in budgetary matters and on sound financial management, OJ C 373, 20.12.2013, p. 1-11

21. European union. (2016). Consolidated version of the Treaty on the Functioning of the European Union, Part six - Institutional and financial provisions, Title II - financial provisions, Art. 312 of the Treaty on the Functioning of the European Union, OJ C 202, 7.6.2016, p. 182-183

22. Ferrer J. N., Cacheux J. L., Benedetto G., Saunier, M., Candau F., Emonnot C., Lachet-Touya F., Mortensen J., Potteau A. and Taranic I. (2016). Potential and Limitations of Reforming the Financing of the EU Budget, Brussels, Expertise commissioned by the European Commission on behalf of the High Level Group on Own Resources under service contract No 14/PO/04, Final version, 3 June 2016, Available at: https://ec.europa.eu/info/sites/info/files/about_the_european_commission/ eu_budget/potential-limitations-reforming-financing-eu-budget_2016_en.pdf [Accessed 30.01.2020].

23. Gallucci, T., Dimitrova, V., \& Marinov, G. (2019). Interrelation between Eco-Innovation and Intra-Industry Trade-A Proposal for a Proxy Indicator of Sustainability in the EU Countries. Sustainability, 11(23), 6641.

24. Haas, J., Rubio, E., and Schneemelcher, P. (2018). The MFF proposal: what's new, what's old, what's next? Policy Brief, Paris and Berlin: Jacques Delors Institute, 21 May 2018.

25. Mahreen Kh. (2018). France, Germany to outline plans for Eurozone budget, FT, 16 November 2018. 
26. National Rural network. (2018). Memorandum - Future MFF - CAP Ministers of agriculture from Finland - France - Greece - Ireland - Portugal Spain Madrid, 31-st of May 2018, Madrid, Available at: https://ruralnet.bg/wpcontent/uploads/2019/05/MemorandumFutureMFFCAPFIN_FR_GR_IRE_PORT_SP .pdf [Accessed 30.01.2020].

27. Nunez-Ferrer, J. and Rinaldi, D. (2016). The Impact of Brexit on the EU Budget: A non-catastrophic event. CEPS Policy Brief, (347). Available at: https://www.ceps.eu/wp-content/uploads/2016/09/Impact\%20of\%20Brexit\%20on\% 20EU \%20budget.pdf [Accessed 30.01.2020].

28. Romanian preliminary position. (2017). Preparing for the post 2020 multiannual financial framework (MFF), Bucharest, December 2017, Available at: https://www.dgfc.sepg.hacienda.gob.es/sitios/dgfc/es-

ES/ipr/fcp2020/fcp2020Demyo/Documents/Estados\%20miembros/Non_paper_MFF_ EN_FINAL_FINAL.pdf [Accessed 30.01.2020].

29. Talaga, A. (2017). Macron's defence visions are suicidal for Poland, EurActiv, 4-th October 2017.

30. The Council of the European Union. (2016). The Bratislava Declaration, Bratislava, 16 September 2016, Available at: https://www.consilium.europa.eu /media/21250/160916-bratislava-declaration-and-roadmapen16.pdf [Accessed 30.01. 2020].

31. The Council of the European Union. (2017). The Rome Declaration, March 2017, Available at: https://www.consilium.europa.eu/en/press/press-releases/2017/03/ 25/rome-declaration/ [Accessed 30.01.2020].

32. Van Berkum, S., Jongeneel, R. A., Vrolijk, H. C. J., Van Leeuwen, M. G. A., \& Jager, J. H. (2016). Implications of a UK exit from the EU for British agriculture: study for the National Farmers' Union (NFU), Warwickshire, UK (Vol. 2016). Lei Wageningen UR.

33. Van Deuverden, K. (2018). EU Commission proposal for 2021-2027 budget: Lost opportunities. DIW Weekly Report, Vol. 8, Iss. 41, pp. 396-402, Deutsches Institut für Wirtschaftsforschung.

34. White, J. and Wildavsky, A. (1989). The Deficit and the Public Interest: The Search for Responsible Budgeting in the 1980s., Berkeley New York: University of California Press Russell Sage Foundation

35. Wildavsky, A. B. (1992). The New Politics of the Budgetary Process. 2-nd ed. New York, NY: Harper Collins Publishers. 